Historic, Archive Document

Do not assume content reflects current scientific knowledge, policies, or practices. 



\section{Fruits and Small Fruits With}

\section{Description of Varieties}

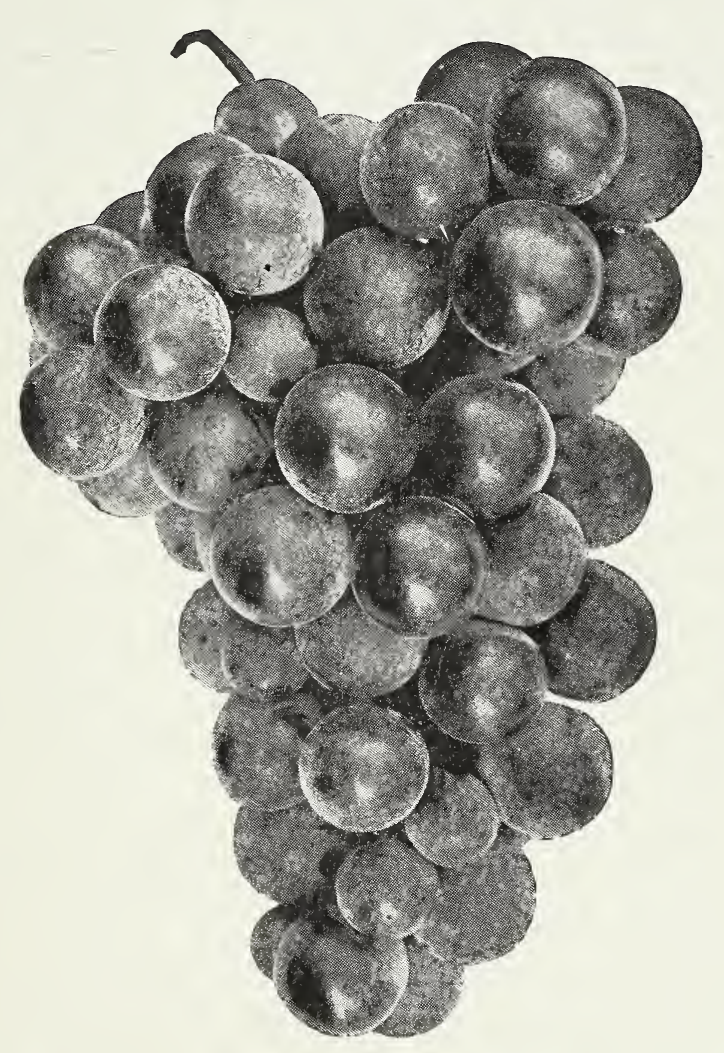

\section{LAFAYETTE NURSERIES}

Lafayette, Indiana

Office and Grounds on Street Railway Adjoining Purdue University on West 


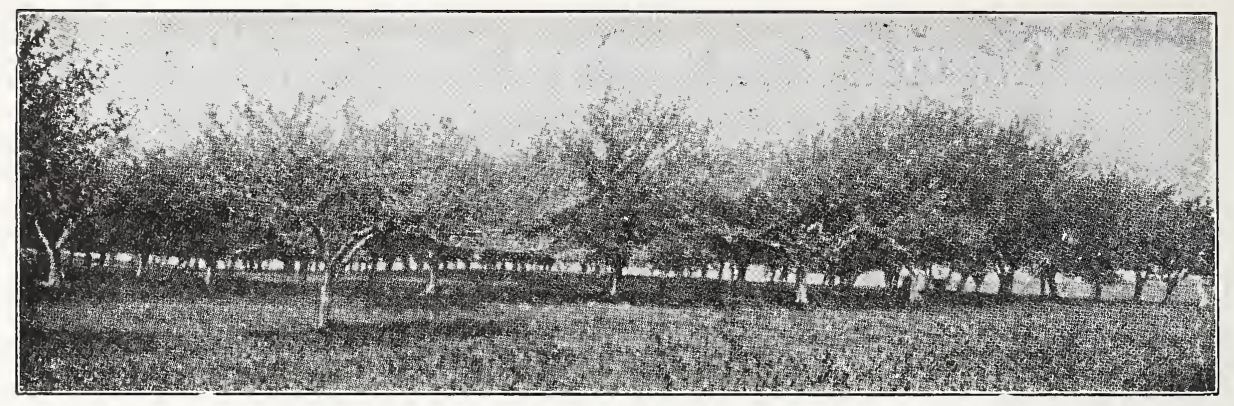

\section{Notice to Our Customers}

We have endeavored to produce a Buyers Guide, which will help acquaint our customers with the better varieties of Fruits and Small Fruits. In this brief publication is found only the better varieties which are adapted to the State of Indiana or a similar climate. It is well known that the range of temperature in Indiana is variable and that a work of this nature must necessarily be general rather than specicific.

It is hoped that our customer's will appreciate this work and we invite criticism of this publication and will appreciate a frank approval or disapproval of any of the subject matter herein. Our descriptions are brief and to the point without any superfluous matter whatever. The list of varieties with few exceptions, known to be suiter to this climate.

liesides the varieties described herein we carry a large number of varieties which will be found in our price list.

It is hoped that you will appreciate this work enough to file it away for future reference, as it is intended as a guide rather than a catalog, an will no doubt be of use in the future for determining varieties to a more or less extent.

\section{FOR PRICES SEE OUR GENERAL PRICE LIST.}

\section{ABOUT VARIETIES.}

The varieties marked (*) are suitable for commercial planting.

\section{SHIPPING SEASON.}

We begin filling orders the latter part of February and continue until about May 1 in the spring. (STRAWBERRIES WILL BE SHIPPED FROM APRIL 1st UNTIL MAY 1.)

In the fall our shipping season begins about October 15 and continues until in December.

\section{FROZEN SHIPMENTS.}

Should any of the stock you receive, become frozen before it is planted, repack it in the container it came in and thaw it out in the cellar gradually, or in a protected place where it is not exposed to the air or rapid changes in temperature.

WE ISSUE A CATALOG ON PEONIES, IRIS, AND PHLOX IN AUGUST, IF INTERESTED SEND FOR A COPY.

If interested in shrubs and ornamental trees send for our booklet entitled HOME BEAUTIFYING SUGGESTIONS.

ORDER EARLY AND DO NOT BE DISAPPOINTED. STOCK IS SCARCE AND EARLY ORDERS GIVE ASSURANCE THAT YOUR ORDER WILL BE FILLED.

We also issue a circular on Tulips, Hyacinths, and Narcissus in the fall. 


\section{Apples the King of Fruit}

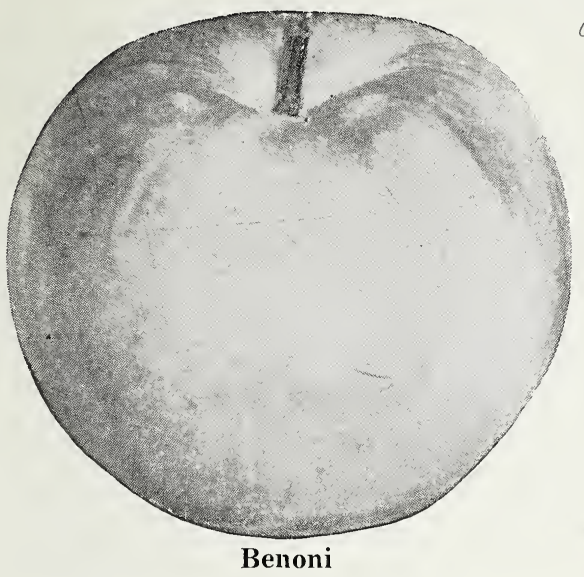

YELLOW TRANSPARENT*-Season. July-August; good size; clear white turning to pale yellow; quality good; flavor sub-acid; an excellent early apple for home use and market; popular market variety; bears early regularly.

BENONI-Season. July-Aug., small to medium; yellow background, red striped; quality good; flavor sub-acid; an excellent early apple for home use but too small for market; yields good crops beinnialy.

DUCHESS OF OLDENBURG*-JulyAugust; medium to large size; streaked with red and yellow, flesh whitish; quality fair to good; sprightly and sub-acid; market variety; tree very hardy, early bearer and fairly productive.

MAIDEN BLUSH*-Season, AugustSeptember; medium size; beautifully flushed with red on creamy yellow; quality fair to good; pleasant but not highflavor; a good market sort because of attractive appearance and all around utility; tree a fair grower and productive.

\section{FALL VARIETIES}

WEALTHY*-Season, August-September; size medium to large; smooth nearly covered with dark red; quality good; dessert; very profitable as a market sort; tree good grower and productive.

McINTOSH - Season, November-February; size, medium to large; yellow, nearly covered with crimson; quality very good; flesh snow white; very crisp, aromatic, sub-acid; popular in North west; tree vigorous and nearly annual bearer.

\section{WINTER VARIETIES}

GRIMES GOLDEN*-Season, OctoberJanuary; medium size; lich golden yellow, sometimes blushed; crisp, aromatic, rich; quality very best; a top notcher on the market. Tree hardy and productive; bears early; blossoms late in spring; frost rarely catches them. One of the best sorts.

JONATHAN*-Season, October-Deember; medium size; brilliant, dark red sometimes has light cheek; quality excellent; flesh white, fine grained, juicy, tender and mild; a delicious and strictly dessert apple that always demands highest market prices; vigorous and productive.

DELICIOUS*-Season, October-January; large to very large; dark red with yellow; quality excellent; fine grained crisp; juicy, melting and delicious; good keeper in early storage and good shipper; home use and market; early bearer and good cropper; tree healthy and vigorous.

WINTER BANANA - Season, October-January; medium to very large; clear pale yellow with blush; good quality; flesh solid, juicy, mild, sub-acid, has delicate banana perfume and flavor; very popular for dessert and market; bears early, almost annually; moderate to heavy crops.

STA YMEN WINESAP*-Season, December-April; medium to large; greenish yellow and red, indistinctly striped; flesh crisp, firm, juicy, good quality tree bears young and is a reliable annual cropper, excellent market variety.

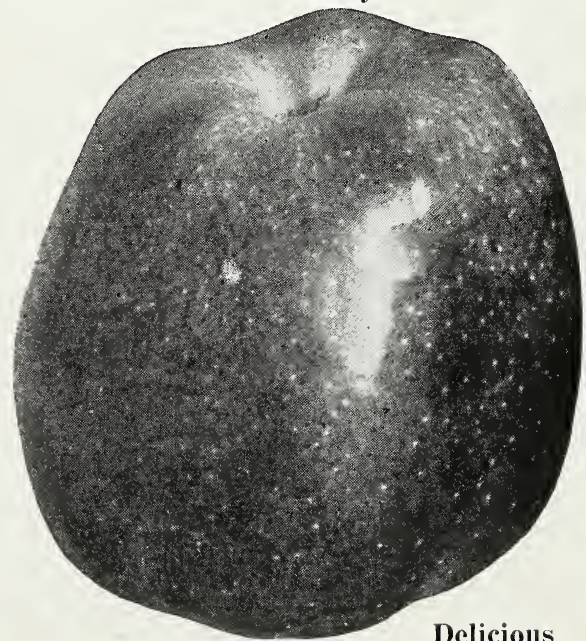


WINESAP*-Season, Jan.-Apr.; small to medium; dark solid red; best quality; tree moderately vigorous with open irregular head, good cropper.

\section{Crab Apples}

WHITNEY - Season, Aug.; large, averaging 11/2 to 2 in.; round, smooth, glossy yellow, red stripes; flesh firm, juicy and rich; almost sweet; especially desirable for cider; tree hardy and productive.

FLORENCE-Season, Sept.-Oct.; medium size; originated in Minnesota. Hardiest of all; an early and profuse bearer; larger than and superier to Transcendent.

\section{Pears}

BARTLETT*-The best summer variety. Season, Aug.-Sept.; large rich yellow, with beautiful blush next to sun; buttery, very juicy and highly flavored. Very popular; grown everywhere. A favorite market variety; tree strong grower; bears early and abundantly.

SECKEL-Medium size; midseason; September; yellow with crimson cheek; flesh melting, sweet and aromatic; most exquisitely flavored pear known; tree slow grower, hardy and healthy.

ANJOU*-Large, midseason, Oct.-Jan. g'reenish shaded with russet-crimson flesh highly flavored and rich; dessert and market sort; keeps well until winter holidays, when it commands a high price. Tree hardy and productive.

DUCHESS*-Very large; green and yellow, with russet; flesh very juicy, with rich excellent flavor. An all around variety for dessert, cooking and market. Succeeds best as a dwarf.

KIEFFER*-Winter variety; October; medium large; yellow and crimson, with russet and brown; flesh firm and good when ripe; the Ben Davis of the pear family; when properly ripened is delicious; tree vigorous, with dark green foliage: an early bearer and productive.

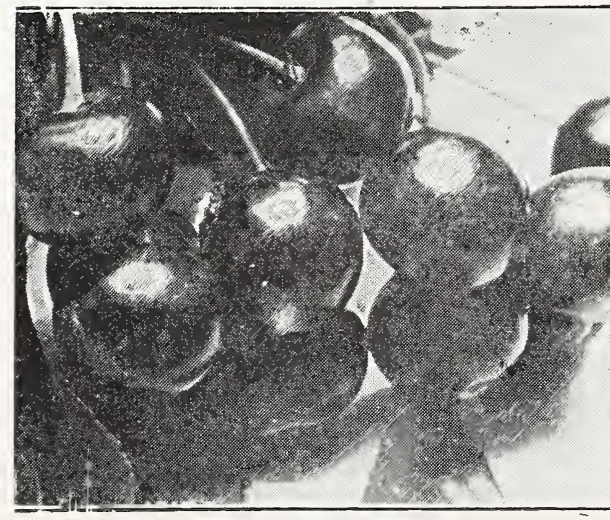

Early Richmond

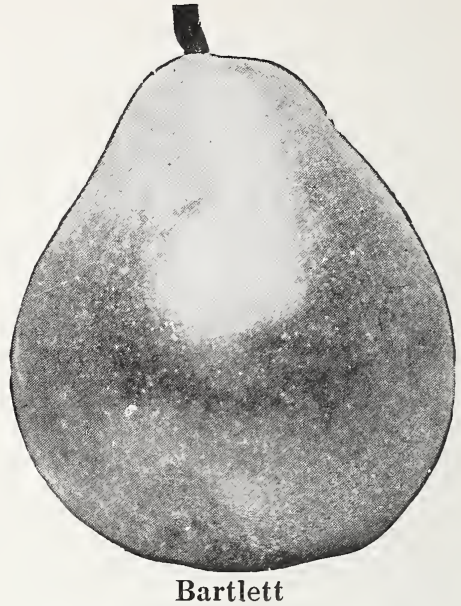

\section{Cherries}

Sour Varieties.

DYEHOUSE-Medium size; red; flesh melting, juicy, with a sprightly tart fiavor. Excellent for canning. Resembles Early Richmond but 5 to 7 days earlier; June; tree upright and hardy.

EARLY RICHMOND*-Medium size; dark red; sprightly acid flavor. This is one of the most valuable and popular of the sour cherries, and is unsurpassed for cooking purposes; tree a splendid grower and is exceedingly productive. Ripens through June.

MONTMORENCY * - Large, round; handsome red; flesh fine flavored, subacid rich; recommended for kitchen and nearby market. Tree good grower, hardy, productive; late June.

WRAGG (Improved English Morello) -Large, roundish, heart shaped; dark crimson and when fully ripe nearly black; flesh and juice light crimson; firm and good; very productive, hardy, and a sure cropper; July.

\section{Sweet Varieties.}

SCHMIDT - Very large, dark reddishblack; flesh dark, tender, very juicy with fine flavor; tree vigorous. The only sweet variety worthwhile in this section.

LAMBERT-Very large, heart shaped; dark purplish-red, turning to almost jet black when fully ripe; flesh very firm, solid, rich and juicy; tree rugged, strong grower, hardy; late July.

TARTARIAN (Black Tartarian)-Is very large; purplish-black, heart shaped flesh mild and sweet and quality considered the very best for market and dessert; tree vigorous upright grower; July. 


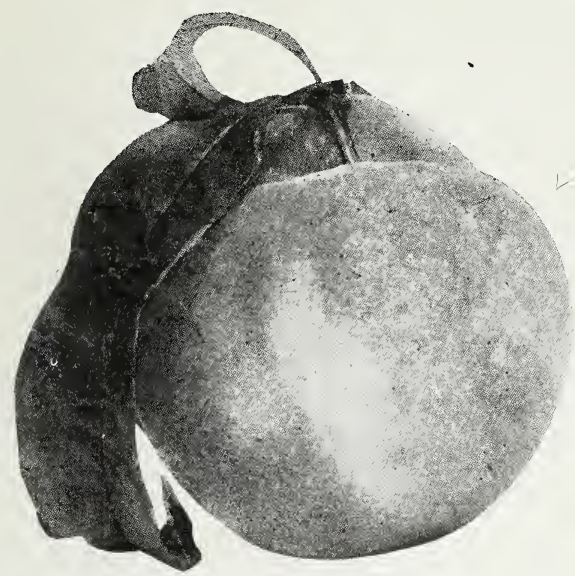

Belle of Georgia

\section{Peaches}

CARMAN *-Aug; semi-freestone white flesh, quality very good; large; tree hardy and productive.

HILEY-Aug.; free stone; large fruit, rich creamy white, with blush; excellent quality; tree vigorus and hardy.

CHAMPION-Aug.; free stone; large, creamy yellow with red blush; flesh white with red stain; delicious, sweet, juicy; tree hardy and productive.

BELLE OF GEORGIA*-Sept.; freestone; white with red cheek; white flesh, firm and excellent flavor; recommended for dessert, home and market; tree a rapid grower, hardy and productive.

J. H. HALE-Sept.; freestone; very large; deep yellow shaded with rich carmine; similar to Elberta but larger and earlier and of about the same quality. A new peach of decided merit. One of the most beautiful peaches grown.

ELBERTA*_Sept.; freestone; yellow flesh, fair quality; a very popular market peach and very productive.

HEATH CLING-Sept.; cling; white flesh, fair quality; large size; originated in Maryland where it is much esteemed.

\section{Plums}

WILD GOOSE*-July; medium to large; red with purplish bloom; cling; flesh yellow, juicy, sweet; recommended for kitchen and market. Tree vigorous and productive.

BURBANK*-Aug.; large; reddish purple; cling; flesh yellow, juicy; good for kitchen or market; tree rather spreading and abundant bearer; very hardy and productive.
DAMSON*-Sept.; small; black, with blue bloom; freestone; flesh juicy, sweet, rich and excellent, rather tart; kitchen and market variety; tree hardy and productive.

GERMAN PRUNE-Sept.; large, long and oval; much esteemed for drying; color dark purple; very agreeable flavor.

GRAND DUKE*_-Sept.; fruit oval with small neck; purple covered with blue bloom; flesh greenish-yellow, adhering closely to the stone; sweet, rich flavor when fully ripe.

GREEN GAGE*-Sept.; roundish oval; greenish-yellow, tough skin; flesh rich, yellow, firm meaty, juicy, mild, sweet, very good; stone free; favorite home and market variety.

\section{Quinces}

CHAMPION-Very large, greenish yellow; flesh cooks up tender without hard spots; delicate flavor; tree vigorous and bears heavy crops; one of the best for sections not subject to early frost.

ORANGE-October; large bright yellow; fine firm flesh of good flavor one of the best for cooking; the most popular of the old varieties.

\section{Apricot}

SUPERB-The only worthwhile variety in this section. A hardy seedling from Kansas. The best flavored, most productive hardy apricot yet produced. Medium size, light salmon color.

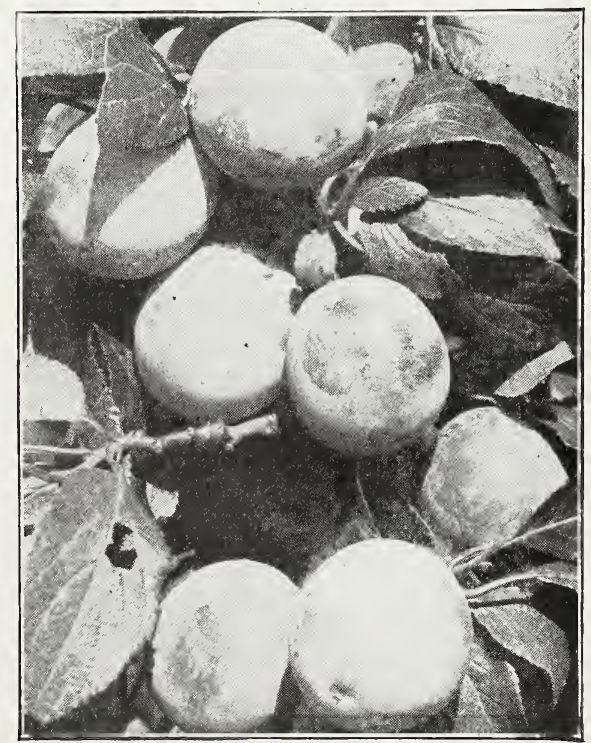

Burbank 


\section{Small Fruits}

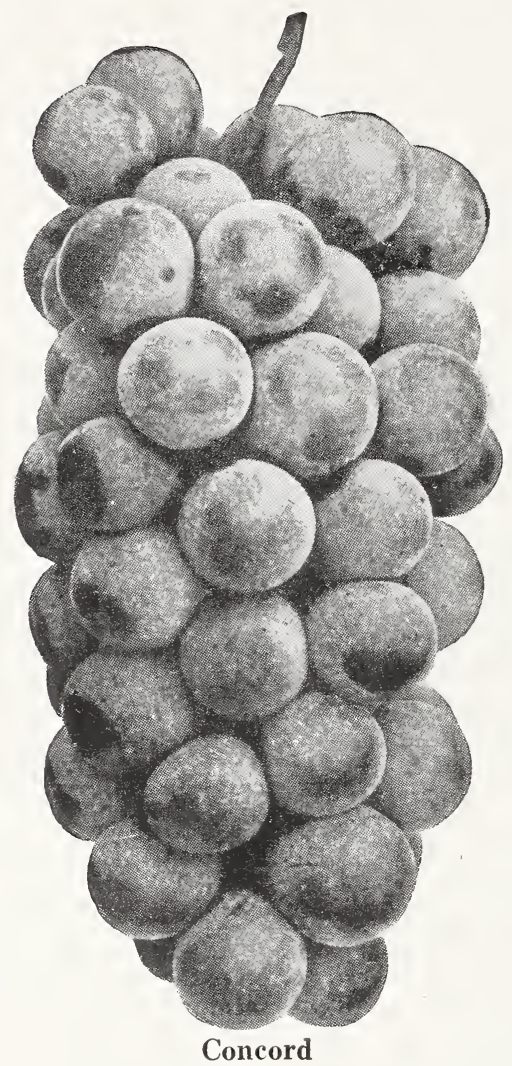

\section{Grapes}

Early Varieties.

MOORE'S EARLY*_Black with blue bloom; very large, round; quality very good and is classed as better and sweeter than Concord; extremely hardy and productive.
BRIGHTON-Red; medium size, flesh rich, sweet and one of the best quality; vigorous and productive and very hardy.

DELAWARE-Red; rather small, lound; flesh juicy without any hard pulp; sweet and spicy and very delicious. One of our very best grapes; vine moderately vigorous, hardy and productive.

\section{Midseason.}

WORDEN*-Black; large, round; delicious and melting; a dessert and market sort considered superior to Concord in every way; vine hardy and productive.

NIAGARA *-White; large, slightly oval; quality equal to Concord and is the standard white grape; bunches are large and compact; vine vigorous, hardy and productive.

CONCORD*_Black; very hardy and productive; ripening about the middle of September. This is one of the most popular grapes for home and market. Concord is the standard black grape; vine vigorous and hardy; highly productive and will succeed on a large variety of soils.

\section{LATE.}

AGAWAM-Red; large, round; large bunched berries, meaty and free from sour pulp; flavor sprightly, moderately sweet.

CATAWBA*-Red; large and round berries; flesh fine flavored and sweet an excellent late sort when fully ripe; well known as the great wine grape.

\section{Raspberries}

\section{Early}

KANSAS*-Very large; black; a berry of splendid quality for general use and popular on the market. In many sections it is the leading sort for extensive planting; vigorous, healthy, and prolific.

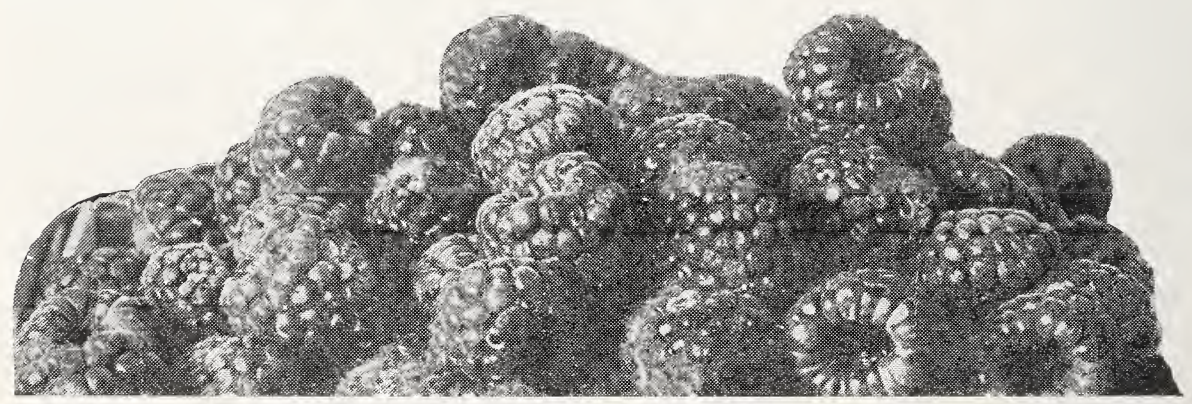

Cuthbert, The Finest of Red Raspberries 
PLUM FARMER*-Black; large, sweet and juicy, but firm; very attractive and recommended for all purposes.

EARLY KING-Red; large, firm, good flavor; dessert and market variety; stands shipping excellently; bush hardy an productive.

\section{Midseason.}

CUMBERLAND*-Black; the largest of all black caps; coal black berries; very firm and quality of the best; excellent shipper; bush strong grower, strong canes and unusually productive.

CUTHBERT*-Red; very large, handsome and firm; flavor rich, sweet and luscious; a great market sort and will stand shipping long distances; stock upright grower and productive.

COLUMBIAN-Purple; very large; sweet and highly flavored; for kitchen and market; very productive.

GOLDEN QUEEN-Yellow, medium large; highest quality; for dessert and kitchen; the best yellow ever produced; hardy, vigorous and productive.

ST. REGIS--(Everbearing). Red; well known everbearer; fruit large, round; fair quality; bears moderately over a long season extending from early in summer to late October. Vigorous grower.

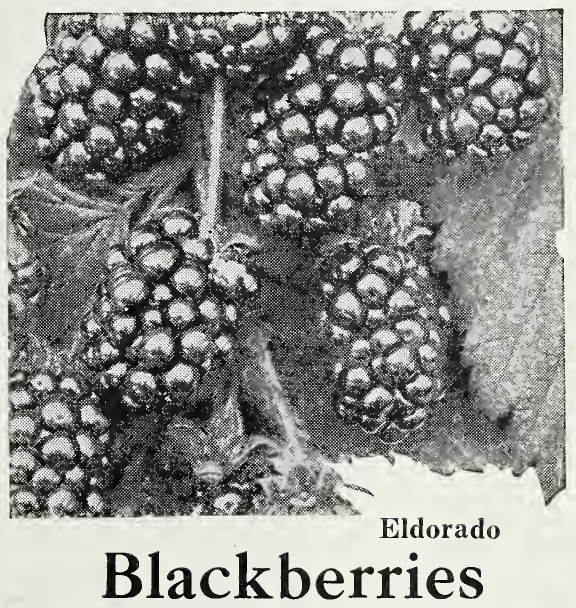

ELDORADO*-Large, black, and do not turn red on exposure to the sun; swcet and melting, having no hard cores; good keeper; vines hardy and productive.

SNYDER*-Medium size, sweet, melting; extremely hardy and very productive; midseason.

LUCRETIA DEWBERRY-Large, jet black, highly flavored and hardy; berries ripen before raspberries are gone; sweet and luscious with no core; the best dewberry ever originated.

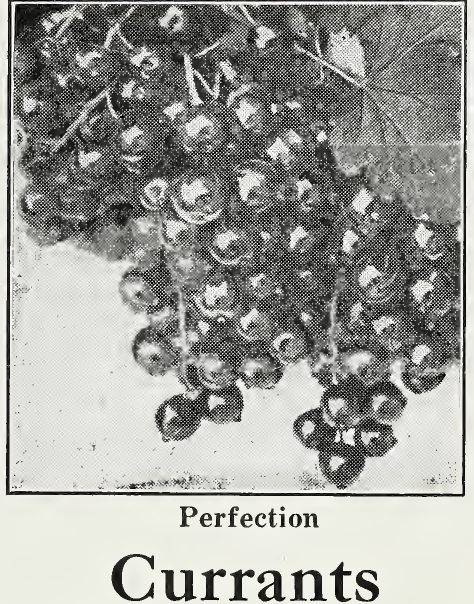

PERFECTION*_Large; upright red; quality very superior, rich, mild, subacid; bush good grower and healthy foliage; long clusters and productive.

LONDON MARKET*-Rather small; red; excellent for market and kitchen; ships any distance; bush hardy; extenssively planted in northern climates; retains its foliage throughout the season; very productive.

WILDER*-Very large; bright red and attractive; a splendid market sort; not so acid as most; large bunches; ripens rather early; fruit keeps well; productive.

\section{Gooseberries}

CHAUTAUQUA*-Very large; greenwhite; white; thin skinned, sweet and of very best quality for kitchen or market; bush vigorous, hardy and free from mildew; midseason.

DOWNING*-Large; roundish; light green, with distinct veins; skin smooth; flesh soft, juicy and very fine flavored; highly estemed for home and market; bush vigorous and productive.

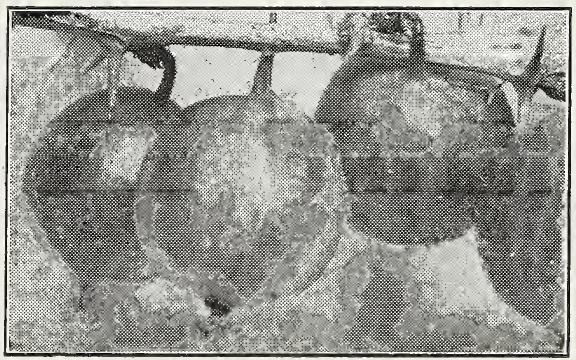

Chautauqua 


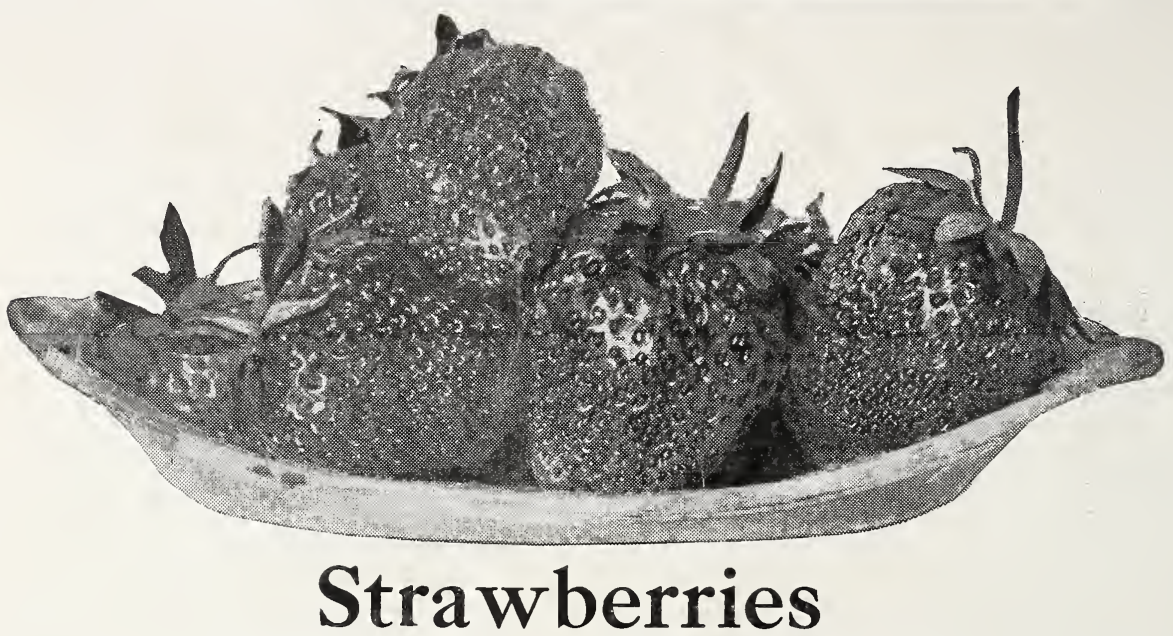

Early.

HOWARD 17*-Perfect; a new variety of decided merit; enormously productive and will no doubt be one of the leaders when stock becomes more plentiful; fruit wedge shaped, rich red with a fine gloss and green seeds. A beautiful and attractive berry; firm, crisp, juicy and very high in quality. Has a record of 17.000 quarts to the acre.

EARLY JERSEY GIANT*-Perfect; a well known early variety; berry long conical to wedge shape, large and fairly uniform; dull red; flesh medium grain, firm, crisp, sub-acid; quality fairly good; plant vigorous and productive.

\section{Medium.}

SENATOR DUNLAP*-Perfect; standard market variety; berry medium size; dark, glossy with golden seeds; flesh fairly firm, and excellent flavor; general

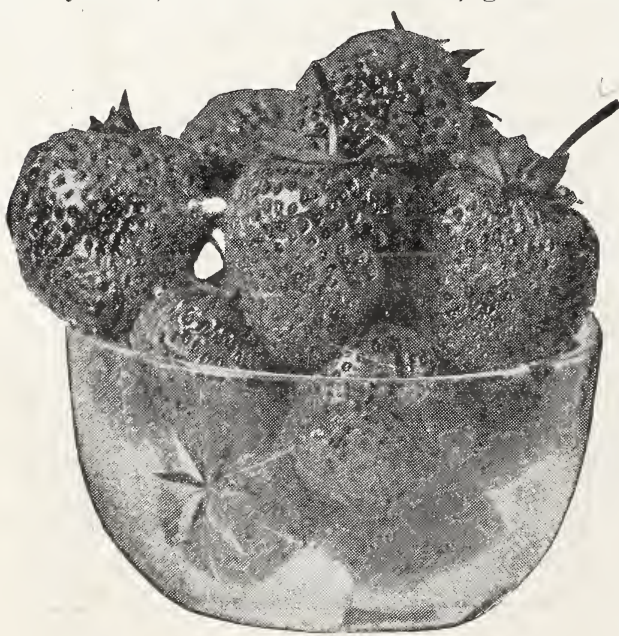

purpose berry; has tendency to make too many runners and consequently the berries run small towards the last of the season; reliable cropper and productive.

GIBSON*_Perfect; a recent introduction which has made a remarkable record and will no doubt crowd Dunlap from first place when the public becomes better acquainted with it. Commences to bear with Dunlap and continues quite late, the berries holding up in size, quality and productiveness. Berry large; dark, glossy red, red flesh; finest flavor; perfect for canning and dessert, and shipping; vines healthy and very productive.

\section{Late.}

AROMA*-Perfect; this is one of the very best late berries; large, firm and of the finest color, and very high quality. Aroma is recognized as one of the leading lates, being healthy with the right amount of runners for a perfect row; very productive.

GANDY*-Perfect; a reliable cropper and a good variety to grow where Aroma cannot be grown with profit. Gandy is one of the old standard varieties. Although not as productive as Aroma, it is reliable and sure; fruit large, attractive, and good quality; good home and market variety.

\section{ASPARAGUS.}

PALMETTO -- Plants vigorous in growth, producing large, thick, dark green shoots with a distinctly pointed tip.

\section{RHUBARB.}

LINNEAUS-Leaf stalks large, tender, juicy produced quite early. A good variety. 